\title{
Virtual Learning Communities: a learning object integrated into e-learning platform
}

\author{
Patricia Alejandra Behar, Ana Paula Frozi de Castro e Souza \\ and Maira Bernardi \\ Education College - Federal University of Rio Grande do Sul (UFRGS) \\ Av. Paulo Gama, 110 - 90.046-900 - Porto Alegre - RS - Brazil \\ \{pbehar,mairaber\}@terra.com.br, nanafrozi@yahoo.com.br \\ home page: http://www.nuted.edu.ufrgs.br
}

\begin{abstract}
COMVIA (COMunidades VIrtuais de Aprendizagem - in portuguese language, is a learning object that cares about virtual learning communities based on standard interaction. In this paper we describe the final results of this study highlighting the ways in which the students interact through the COMVIA object in e-learning situations. Also present in the article are the main characteristics of a learning objects and how it can be integrated into a virtual platform.
\end{abstract}

\section{Introduction}

The present article is a reflection upon the theoretical references of the learning object COMVIA ${ }^{1}$, its building steps and its application for tests and validation in a post graduate $^{2}$ discipline that has resulted in the formation of virtual learning communities. It is an object about Virtual Learning Communities, the use of COMVIA in the afore mentioned discipline was precisely to check the level of the object resources in relation to these requirements. It was used in the Federal University of Rio Grande do Sul, Brazil, in the graduate and post graduate courses of the Education College. It was integrated in the virtual learning environment called ROODA $^{3}$ used by this institution.

${ }^{1}$ Available in: http://www.nuted.edu.ufrgs.br/instrumentalizacao_em_ead/comvia

${ }^{2}$ Discipline SA: Oficinas Virtuais de Aprendizagem - in post graduate level in Education and Computer Education throughout 2007/1.

${ }^{3}$ Rede cOOperativa de Aprendizagem - distant learning education platform from UFRGS. Available in: www.ead.ufrgs.br/rooda 


\section{The Learning Object COMVIA}

In this study, Learning Object is understood as any digital resource such as: texts, animations, videos, images, applications, Web pages combined. Its utilization is aimed at learning situations, either distant or presential. According to LTSC ${ }^{4}$, these can be defined by any entity, digital or non digital, that can be utilized, re-utilized or referenciated during technology-mediated learning.

COMVIA is a Learning Object about virtual learning communities based on interactionist premises. This tool fosters students'active participation in the construction of knowledge and cognitive development. Its utilization is aimed at learning situations, either presential or distant.

COMVIA was developed in four main phases: project concept, planning, implementation and evaluation, observing necessary criteria for the development of learning projects as defined by Amante \& Morgado [1]. These phases are: (1) Project Idea, when the project, key lines and intended applications were defined following the groups' initial idea. (2) In the Planning phase research was made for its development, the study of storyboard and navigation paths due to its non-linear structure. (3) The implementation phase refers to the development per se, where the programming tool to be used is defined and the first prototypes of the object are elaborated until they reach their final version. (4) In the Evualution phase, were perform tests to verify the functionality of the object. COMVIA was finalized with eight resources. Among COMVIA resources are: Base Theories, Contents, Challenge Bank, COMVIA TV, Library, COMVIA guide, Glossary and Help.

\section{Validation of COMVIA in post graduate level through a long distance education platform}

Throughout 2007/1, COMVIA was piloted in SA discipline: Virtual Learning Workshops, in the Computer Education Science and the Education post graduate courses at UFRGS. This discipline covers a multi disciplinar area of knowledge that integrates Digital Technology with Education, innovative in the use it makes of distant learning environments. The objective of this discipline is the study through workshops to be carried out in the virtual learning environment ROODA. In such post graduate discipline, students had contact with COMVIA through the workshop about Virtual Learning Communities. Therefore, the students were, at the beginning, invited to explore the resources of Learning Object, among them Base Theories, Contents, Library and Glossary. All the activities were carried out with the support of the virtual learning environment ROODA, using the Forum, Webfolio, Diary, Class, Chat, Groups and A2 tools. There were four meetings, three of them presential and one virtual, a total of 20 hours.

\footnotetext{
${ }^{4}$ Learning Technology Standards Committee - http://ltsc.ieee.org/wg12
} 


\subsection{Integrating COMVIA object and ROODA platform}

Workshops were structured so that the learning object COMVIA could present its contents and challenges to participants in a dynamic and interactive way, through challenges, videos, texts and links. ROODA virtual environment was used so students could have a place to carry out their interactions. Experience exchange and interaction among students were encouraged during the discussions about the themes being worked on, through the ROODA environment.

During the presential classes, aspects regarding the conception, creation and pedagogical implications of virtual learning communities in different educational contexts were discussed. In the virtual meeting, students met online, using the ROODA environment in order to solve the challenges assigned.

The challenges were carried out in groups. The students needed to meet virtually or face-to-face out of class time. This necessity made it possible for these students to constitute a virtual space with their groups, through the environment ROODA that resulted in the constitution of collective spaces among participants. It was possible to observe, thus, the formation of virtual learning communities within the group to carry out the challenges that were proposed.

\subsection{Why integrate DL platforms and learning objects?}

The use of a distant learning platform integrated with the learning object was paramount for synchronous and assynchronous interaction among students, through the functionalities it offers. This way, during the class period, several themes/challenges made available by the learning object were discussed and collective spaces were created, allowing for cooperative work. Such endeavor made it possible to observe the actual experience of a learning community among participants during the workshops. Interaction is a dialectical and complex process of exchange and of meanings from which subject and object change [2]. In this perspective, action becomes the exchange instrument, and knowledge is built through schemes and coordinated actions. The subject is understood as a totality constituted by internal factors (maturation) and external factors (environment). Such interactive process allowed the students themselves to be mediators of their learning, learning through a cooperative process [3].

Hence, as a result of the application of this learning object through ROODA environment, students (and support team) created a moment of reflection and of knowledge production about the concepts of virtual learning communities, registered throughout the production and elaboration processes, published by the groups.

The concept of communities was developed through the COMVIA object and it presents communities as a group of subjects that establish interdependent relationships, within a complex social framework, with specific and individualizing characteristics [5]. The Virtual Learning Communities set themselves as electronic networks of interactive communication, organized round a mutual project. They constitute themselves from common knowledge interests, shared goals and exchange values, established through a cooperative process. The formation of such networks could be observed in the course, as well as its maintenance for study of new contents. According to Paloff e Pratt [2], the community is the vehicle through which learning occurs. As a result, it was also necessary to promote autonomy, initiative and 
creativity of each group, so that a sense of belonging to the community could be observed by participants of the discipline.

Because of its non-linear character, the object contributed for actions that did not take certain pathways determined a priori, observing linearity but built upon connections, additions, what Lemos [4] defines as a "stroll through cybernetic space". It is understood that this adequation encompasses the formation of a concept about the actions that were taken. The intended goal was not to have the students do the activities using the tools of the environment but that they expressed their awareness about their actions.

In this perspective, we could observe that the students dealt with the information available in the object as their own, through the experiences exchanged throughout the period the class was going on. This was possible because they themselves formed virtual learning communities with the support of ROODA's functionalities.

\section{Final Considerations}

To conclude we can say that integration between the learning object COMVIA and the platform ROODA made interaction possible among students of the workshop, constituting a collectivity among them. Such collectivity culminated with the formation of virtual communities that could be observed throughout the presential and long distance meetings, resulting in good quality final productions by the groups.

Thus COMVIA is a tool to be used by teachers in their formative process, students and other web users. It is believed that the object can help the theoretical and practical instrumentalization of its subject matter, through different technological resources that can be employed in different areas of knowledge. For this matter, the object was published in the CESTA $^{5}$ repository of learning objects. Such repository allows for publication and reutilization of learning objects by any user in any course.

\section{References}

1. Amante, Lúcia. Morgado, Lina. (2001) "Metodologia de concepção e desenvolvimento de aplicações educativas: o caso dos materiais hipermídia”. In: Discursos. Lisboa, Portugal. [III Série, número especial]: 27-44, junho.

2. Behar, P. A. ; Leite, Silvia Meirelles ; Bordini, Sandra ; Souza, Lúcia Barros De ; Siqueira, Luciano Goularte (2007b). Avaliação de Ambientes Virtuais de Aprendizagem: O Caso do ROODA na UFRGS. Revista Avances en Sistemas e Informática, v. 4, p. 81-100,

3. Duran, David; Vidal, Vinyet. (2007) Tutoria: aprendizagem entre iguais: da teoria à prática. Tradução Ernani Rosa. - Porto Alegre: Artmed.

4. Lemos, André. (2002) "Cibercultura: tecnologia e vida social na cultura contemporânea". Porto Alegre: Sulina.

5. Paloff, Rena M. e Pratt, Keith. (2002) "Construindo comunidades de aprendizagem, no ciberespaço: estratégias eficientes para salas de aula on-line". Porto Alegre: Artmed.

${ }^{5}$ Available in: http://www.cinted.ufrgs.br/CESTA 